\title{
Planting of Seedlings and Direct Seeding with Different Inputs in Pioneer Species in the Southeastern Amazon
}

\author{
Antônio Carlos Silveiro Silva ${ }^{1}$ (D) 0000-0002-8180-825X \\ Rubens Marques Rondon Neto ${ }^{2}$ \\ Norberto Gomes Ribeiro Júnior ${ }^{1}$ \\ Jessica Borges da Veiga ${ }^{3}$ \\ Charles Caioni ${ }^{1}$ \\ Wesley Vicente Claudino ${ }^{3}$
}

\begin{abstract}
The main objectives of the study were to determine which was the best implantation of forest method between direct seeding and planting of seedlings, the use of Slow Release Fertilizer (SRF) and hydrogel in the pioneer species Schizolobium parahyba var. amazonicum and Senegalia polyphylla, and the use of morphometric indices, such as slenderness of trunk and canopy, to assist in growth evaluation. Generalized Linear Model (GLM) and Principal Component Analysis (PCA) were used as the main methods. The morphometric indices, plus the variables height, trunk and canopy diameter, provided complementary information on the morphological growth pattern of the plant. For both species, both direct seeding and planting of seedlings promoted good results in the growth variables, with the planting of seedlings showing better results in Senegalia, however, not enough statistical clarity for Schizolobium. Regarding inputs, the SRF promoted the best results and therefore this fertilizer was recommended for a complementary input in forest implantation.
\end{abstract}

Keywords: hydrogel, slow release fertilizer, canopy slenderness, trunk slenderness, overhang index.

\section{Introduction}

Riparian forests (or riparian woodland) are also affected by the replacement of natural vegetation to pasture and/or agricultural areas in the Brazilian Amazon, despite being a permanent preservation area according to the Brazilian Forest Code (Brasil, 2012). These changes put at risk its freshwater ecosystem services, such as soil stabilization, pollutant filters, landscape connectivity between terrestrial and aquatic biodiversities, in addition to affecting the quantity and quality of water (Zimbres et al., 2018; Helfenstein \& Kienast, 2014; Souza et al., 2013). Depending on the degree of alteration, riparian forests may have their resilience capacity compromised, which results in the need for anthropic intervention to assist in the ecological recovery process (Ceccon et al., 2016). Active restoration, which can help this process, basically consists of the implementation of species in the area and, according to Almeida (2016), when they are pioneers, these species allow a rapid soil cover and a change in microclimate that helps the final stages of succession. Even more, when natural regeneration of late trees in fragmented and degraded landscapes can be strongly compromised (Leitão et al., 2010).

Direct seeding and planting of seedlings are two methods widely used within active restoration for the rehabilitation of degraded environments (Ceccon et al., 2016; Grossnickle \& Ivetić, 2017). The planting of seedlings is the most widely method used to cover degraded environments and can accelerate the recovery and succession process due to the "rustification"

\footnotetext{
${ }^{1}$ Universidade do Estado de Mato Grosso (UNEMAT), Programa de Pós-graduação em Ecologia e Conservação, Nova Xavantina, MT, Brasil

${ }^{2}$ Universidade do Estado de Mato Grosso (UNEMAT), Curso de Engenharia Florestal, Alta Floresta, MT, Brasil

${ }^{3}$ Universidade do Estado de Mato Grosso (UNEMAT), Programa de Pós-graduação em Biodiversidade e Agroecossistemas Amazônicos, Alta Floresta, MT, Brasil
} 
(or local adaptation) and adaptation of seedlings in nurseries (Almeida, 2016; Ceccon et al., 2016). The disadvantage of this method is its high implementation cost and the difficulty of obtaining seedlings for a larger area (Florentine et al., 2013). The direct sowing consists in inserting the seed directly in the area to be restored and, by dispensing nursery's production practices, it becomes a low-cost alternative in forest restoration (Huller et al., 2017; Ceccon et al., 2016). For both methods, there are several implantation of forest models, such as diversity islands and planting in lines (Holl et al., 2011), and the last one is established by planting of species throughout the area to be restored and used in this research with the pioneer species Schizolobium parahyba var. amazonicum (Huber ex Ducke) Barneby and Senegalia polyphylla (DC.) Britton \& Rose.

Schizolobium parahyba var. amazonicum is a species belonging to the Fabaceae family, with a large occurrence in the South America (Reis \& Paludzyszyn, 2011). It is a large and fast growing species (Cordeiro et al., 2015), and due to its adaptive characteristics to the diverse edaphoclimatic conditions, the species presents good performance in homogeneous formations, and has been cultivated in reforestation for recovering degraded areas in the Amazon region (Santos et al., 2016; Carvalho et al. 2016; Cordeiro et al., 2015). Senegalia polyphylla also belongs to the Fabaceae family, and is distributed in the five Brazilian phytogeographic domains (Morim \& Barros, 2015). Due to its rusticity and rapid growth, the species is very suitable for the recovery of degraded areas and is also relevant in reforestation programs based on mixed planting and aimed at the recovery of permanent preservation areas, as well as management of forest fragments and landscape projects (Maia-Silva et al., 2012; Nunes et al., 2015; Carnevali et al., 2016).

In addition to the implantation of forest methods, the forestry managers use certain inputs to strengthen the establishment of the species in the field, such as the use of Slow Release Fertilizer (SRF) and the hydrogel. Thus, the SRF or controlled release fertilizer, as its name suggests, releases the nutrients into the soil in a more prolonged and homogeneous way than traditional fertilizers, which allows the availability of nutrients for plants over a longer period (Yamamoto et al., 2016; Machado et al., 2011). On the other hand, hydrogels are defined as three-dimensional polymer networks and are able to absorb large amounts of water that may be available to plants. Therefore, the distribution of water and nutrients in the soil is important for forestry managers, taking into account that for the development of the plant, the use of water and nutrient is necessary (Elbarbary \& Ghobashy, 2017). However, the combination of SRF and hydrogel seems to be significant for creating a microenvironment favorable to the development of forest species in the early stages.

After the implantation of forest process in the field, the evaluation of performance of the species was assessed and represented one of the main stages, because they are complex. In addition, the evaluation of the spatial organization of trees in the forest, at a given time, is one of the fundamental objectives for forest researchers (Dassot et al., 2011). The most commonly measured variables are the Diameter of Breast Height (DBH), the individual's height and the horizontal canopy projection, the last method is used to assess canopy coverage (Malhi et al., 2018). The canopy is an extremely important component of vegetation, seeing that it is related to photosynthesis, energy interactions (transpiration) that affects the regional and global climate, biogeochemical cycles, in addition to being recognized as a biological diversity hotspots (Lowman \& Schowalter, 2012; Nakamura et al., 2017). Thus, as the canopies are vertically stratified ecosystems and interconnected with other strata, the branch architecture is an essential link of leaf development with the rest of the plant (Nakamura et al., 2017; Dassot et al., 2011). Thus, the mathematical combination of height, diameter of the trunk and the canopy of the trees provide several morphometric descriptors of plants in the field. For instance, the canopy slenderness (see details in Tomczak et al., 2015), trunk slenderness, overhang index, index comprehensive and canopy ratio can be noted (see details in Durlo \& Denardi, 1998).

The relationship between the total height and the diameter of the trunk is described as slenderness, which may be a good indicator of plant stability and has been used in forestry for many years because it can be estimated easily (Rust, 2014; Tomczak et al., 2015). The slenderness of the canopy, which is the relationship between the height of the canopy and the diameter of the canopy, is also another indicator of plant stability (Tomczak et al., 2015). The canopy ratio refers to the relationship between the canopy length and the total height of the plant, and when expressed as a percentage, it shows the canopy space filling. The overhang index designation is linked to the relationship between the canopy diameter and the $\mathrm{DBH}$, and expresses how many times the first data is significant relevant compared to the second. Similar to the overhang index, the index comprehensive is obtained by the relationship between the canopy diameter and the total height of the plant. All of these indexes, plus the basic variables (height, trunk and canopy diameter), have implications for the management and silviculture of an area with forest species, comprising the idea of interdimensional relationships, in addition to inferences about vitality, stability and productivity (Durlo \& Denardi, 1998; Tomczak et al., 2015; Rust, 2014).

Studies evaluating these two methods of forest implantation (direct seeding and planting of seedlings) regarding neotropical pioneer species are scarce in ciliary areas, especially in combination with the SRF and hydrogel inputs, as well as the use of morphometric variables of the trunk and canopy. Thus the objective of this manuscript was to: i) verify which method of forest implantation is most appropriate for both species after 
30 months of implantation; (ii) verify the performance of SRF and hydrogel applications on the growth of Schizolobium and Senegalia plants; and (iii) relate the most common variables (trunk diameter, canopy diameter and total height) with trunk and canopy morphometries.

\section{Materials and methods}

\subsection{Study area}

The experiment was carried out in an area of degraded riparian forest situated in the metropolitan area of the city of Alta Floresta, in the state of Mato Grosso (MT) (Bleich \& Silva, 2013), at the geographic coordinates of $09^{\circ} 49^{\prime} 58^{\prime \prime} \mathrm{S}$ and $56^{\circ} 03^{\prime} 22^{\prime \prime} \mathrm{W}$, at $284 \mathrm{~m}$ (Figure 1). The experimental area is approximately $3,000 \mathrm{~m}^{2}$, located on the shores of a perennial watercourse with an average of $2 \mathrm{~m}$ in width. Previously, the experimental area was abandoned and dominated by Urochloa brizantha ((Hochst. ex A. Rich.) R.D. Webster) and Baccharis sp. Currently, in addition to the watercourse, the focal area is surrounded by pastures.
The soil of the experimental region is classified as Dystrophic Red-Yellow Latosol. The original area was composed of open ombrophylous forest. The altitude of the region is $200-300 \mathrm{~m}$, with an annual average temperature of $26^{\circ} \mathrm{C}$ and an annual precipitation in the range of $2800-3100 \mathrm{~mm}$ (Alvares et al., 2013), which falls within the climatic zone Am (monsoons).

\subsection{Methodological procedures}

The forest species were implanted simultaneously and randomly in the study area and used the following steps to perform the experiment consisted in area preparation, seed collection and production of seedlings, planting of seedlings and direct seeding, in addition to applied treatments and maintenance of the area. For preparing the area, it was necessary to isolate the last one in order to avoid possible damage caused by animals. The $1 \mathrm{~m}$ wide planting strips, with a $2 \mathrm{~m}$ distance from each other, was used. After that, the soil was prepared in minimum cultivation that consisted of the two plowing of planting strips at the depth of $\pm 25 \mathrm{~cm}$. The seeds of the two forests species were collected in September 2011, in species that naturally occur in forest fragments located in the proximity of

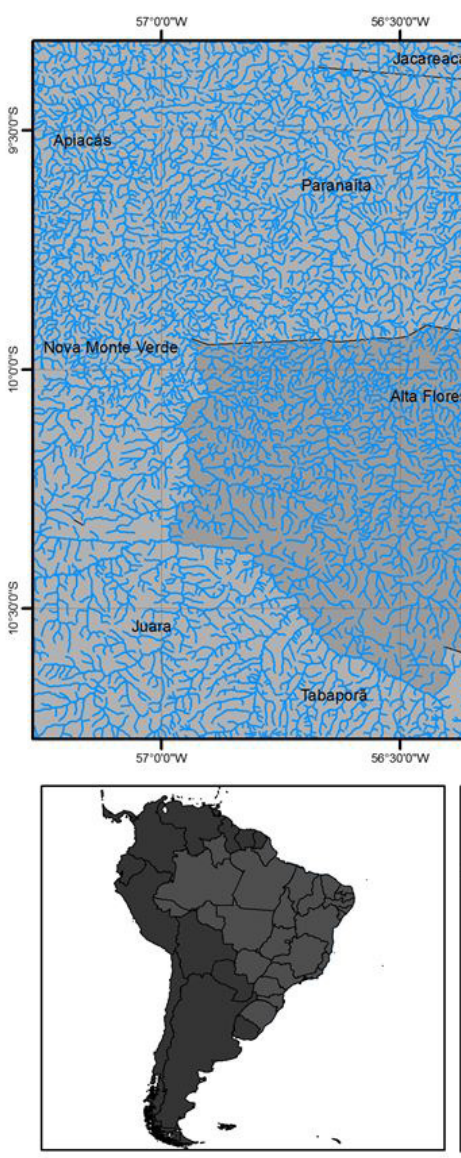

56"0.0w
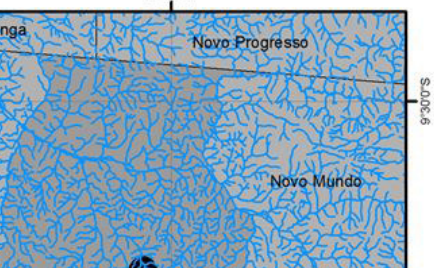

40
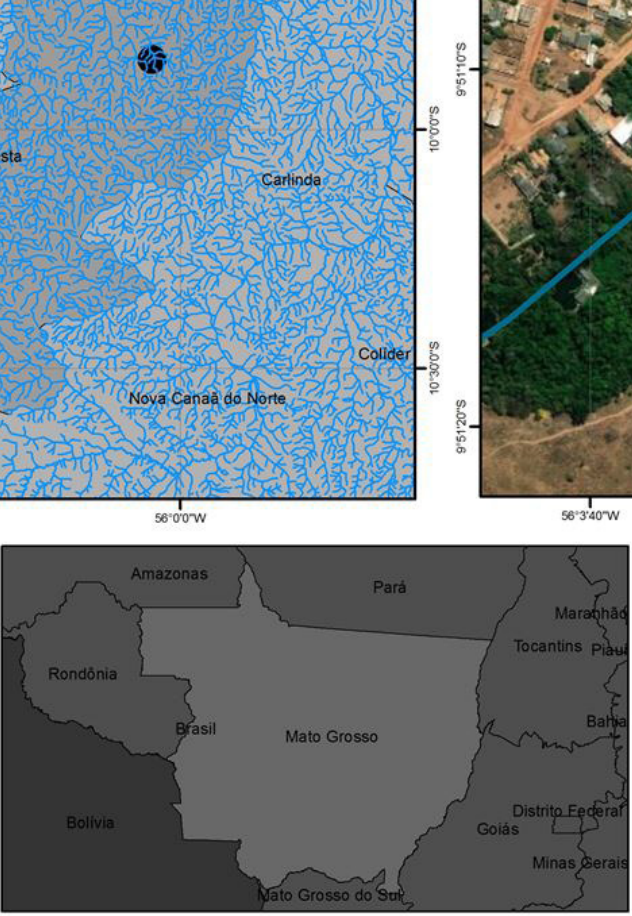

Legend

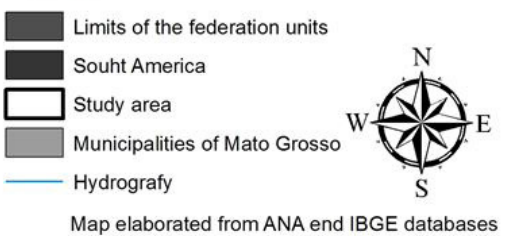
Geographic coordnate systems DATUM WGS 1984

Figure 1. Geographical location of the experimental area located in the municipality of Alta Floresta, in the state of Mato Grosso. 
the city of Alta Floresta, MT. From some of the seeds, seedlings were produced in tubes of $50 \mathrm{~cm}^{3}$, filled with commercial substrate of the Rohrbacher ${ }^{\circledR}$ brand with semi-composite pine bark, coconut fibre, and vermiculite. The planting of seedlings and direct seeding were performed in $2 \times 2 \mathrm{~m}$ spacing, made in $25 \mathrm{~cm}^{3}$ pits in December 2011. At each direct seeding site, three seeds were placed, and after germination, they were thinned leaving only one plant per point. Regarding the treatments, the hydrogel and SRF as inputs for the two forest species were used. The hydroretent was applied inside the pit at the rate of $400 \mathrm{ml}$ per plant, which was prepared in the proportion of $3.0 \mathrm{~g} \mathrm{~L}^{-1}$ of water. Similarly, the SRF $\left(\right.$ Osmocote ${ }^{\circledR}$ ) was used in the ratio of $20 \mathrm{~g}$ of NPK fertilizer (10-20-20) per pit. Thus, for each forest species were evaluated eight treatments according to Table 1 .

For the maintenance of the area, granulated baits and powder based on sulfluramide to control leaf-cutting ants were used. Through mechanical mowing and manual crowning performed with a hoe ( $50 \mathrm{~cm}$ of radius of the plant), the control of the invasive plants could be maintained. And after 30 months, it could be measured and estimated several morphometric variables and the schematic representation is shown in Figure 2. In addition, the survival variable for the same period could be obtained.

The Diameter at Ground Height (DGH) was measured with a digital caliper, expressed in millimeters. In addition, the diameter at the height of the soil was measured because the plants were very young. The total height $(\mathrm{H})$, distance from

Table 1. Arrangement of treatments in relation to the two implantation methods and inputs used in this work.

\begin{tabular}{ll}
\multicolumn{1}{c}{ Planting of seedling } & \multicolumn{1}{c}{ Direct Seeding } \\
Control (S) & Control (DS) \\
Hydrogel (SH) & Hydrogel (DSH) \\
Fertilizer (SF) & Fertilizer (DSF) \\
Fertilizer + Hydrogel (SFH) & Fertilizer + Hydrogel (DSFH) \\
\hline
\end{tabular}

Observation: For each treatment, four replicates were performed, each one with six plants.
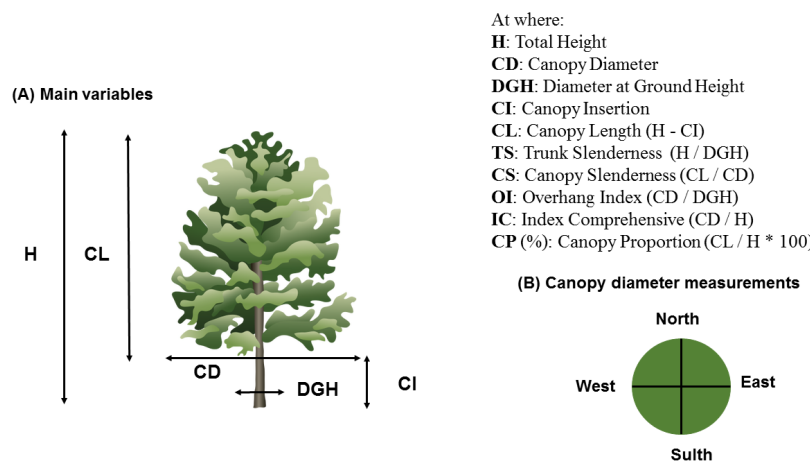

Figure 2. (A) Representation of the variables measured and estimated at work; (B) Model for obtaining the canopy diameter. the base of the trunk to the apex of the plant, and the Canopy Insertion (CI), which refers to the distance from the base of the trunk to the beginning of the canopy, were obtained with a graduated stick, in meters. The Canopy Diameter (CD) consisted of measuring the two ends of the canopy of each individual, following the directions of the cardinal points (north, south, east and west), with the aid of a measuring tape, also expressed in meters. The survival assessment considered the numbers of individuals alive in each treatment.

\subsection{Data analysis}

For the first and second objective of the work, each variable was submitted to the Generalized Linear Model (GLM), in which the Gaussian frequency distribution was used, with the aid of software R. The Tukey's test was applied in the sequence with the aid of the 'agricolae' package (Mendiburu, 2017). For both models, the structure was organized in a $2 \times 4$ factorial scheme, with two implantation methods and four treatments per species. For the third objective, all variables were submitted (except survival) to the Principal Component Analysis (PCA), to verify the linear associations between the descriptors and the main axes of the analysis using software $\mathrm{R}$, version 3.4. 2 ( $\mathrm{R}$ Core Team, 2017), including the FactoMineR package (Le et al., 2008), the graphical output with the factoextra (Kassambara \& Mundt, 2016), and ggplot2 (Wickham, 2009). In addition to PCA, the Spearman rank correlation was listed for all variables.

\section{Results}

The first two components collected more than $65 \%$ information on the morphometric variables for both species (Figure 3). The two methods of implantation of forest, Direct Seeding (DS) and Planting of Seedlings (PS), strongly evidenced their division in Senegalia, and regarding the diagram, the planting of seedlings passes to the results on the right side and the direct seeding to the left. The variables that contributed the most to the first component were H, DGH, Canopy Diameter (CD) and Canopy Length (CL) for both species. The second axis was represented by the canopy morphometry, where the Canopy Slenderness (CS), Canopy Insertion (CI), Canopy Proportion (CP) and Overhang Index (OI) for Schizolobium, and CP, CI and CS for Senegalia, were the most correlated variables with this component, respectively. In addition to PCA, the correlation pairs between the descriptors of Senegalia and Schizolobium are shown in Table 2. The highest correlations were found for the main growth variables (DGH, H, CD, CI and CL), which contributed to the majority of the first axis of PCA. In relation to these same variables, which contributed to the 

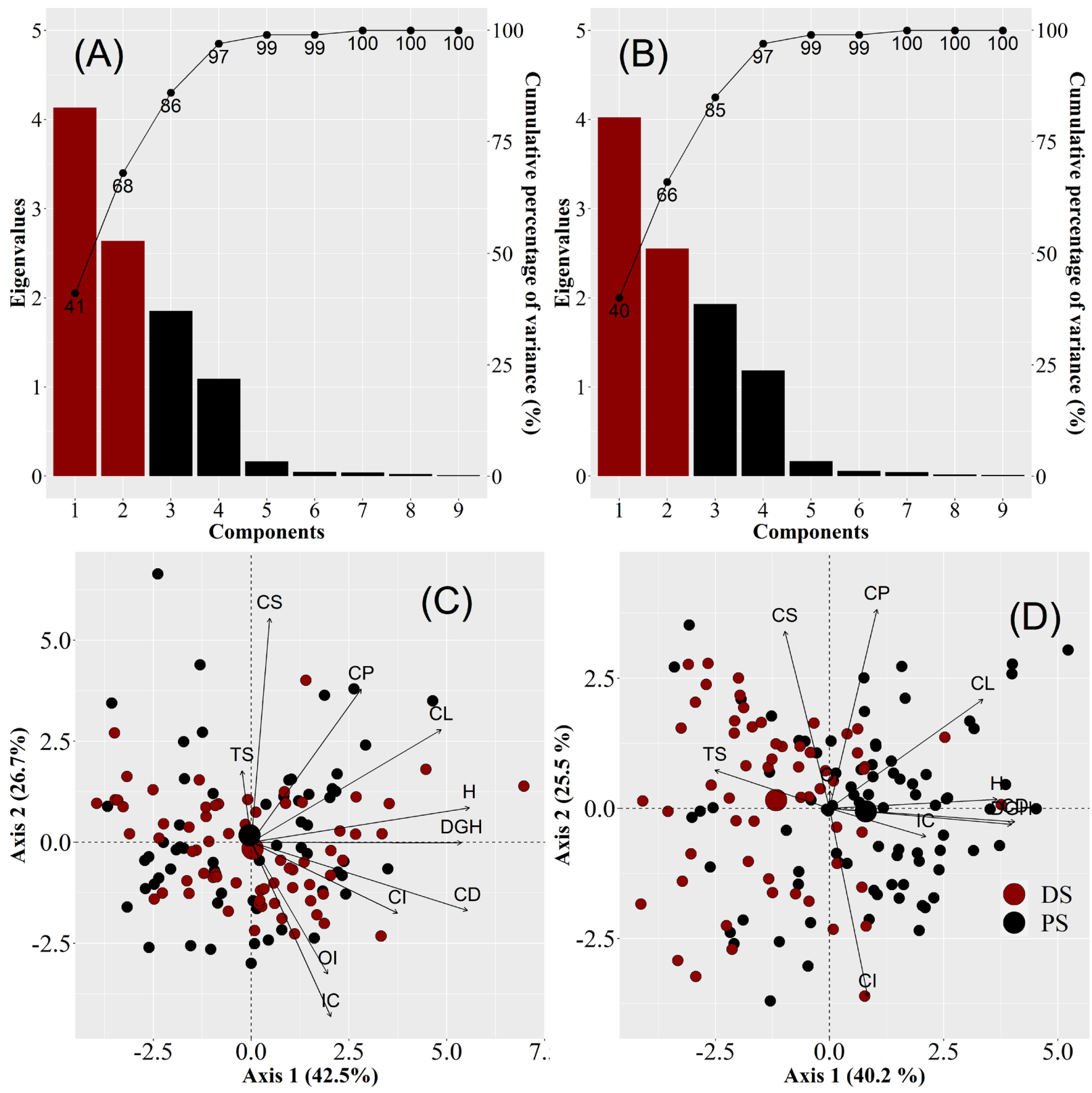

Figure 3. (A) and (B) Eigenvalues and cumulative variance for Schizolobium e Senegalia, respectively - in red can be seen eigenvalues used in this work; (C) and (D) Diagram of the principal component analysis of Schizolobium and Senegalia, with the division of the forest implantation methods, PS: planting seedlings; DS: direct seeding; TS: trunk slenderness, CS: canopy slenderness, CP: canopy proportion, CL: canopy length, H: total height, DGH: diameter at ground height, CD: canopy diameter, CI: canopy insertion, OI: overhang index, IC: index comprehensive.

first axis, height was significantly associated with PC and SC for Schizolobium, but was only associated with Trunk Slenderness (TS) for Senegalia. For the diameter, the highest correlations were for PC, in Schizolobium, and TS for Senegalia. In relation to the indexes, the CS correlated significantly and positively with the canopy proportion in both species (especially in the Schizolobium, $r$ above 0.7 ), in relation to the indices of coverage and salience. The correlation between slenderness was more noticeable in Senegalia, and as expected, the trunk slenderness was positively positioned with the salience index and negative with the coverage index, being less noticeable in Schizolobium.

The implantation of Senegalia via seedling planting presented the highest results in contrast to direct seeding for almost all the significant variables: DGB (82\%); H (41\%); CD (47\%); CL (45\%); CA (104\%) and Survival (41\%) (Figure 4). On the other hand, the exception was related to TS $(-35 \%)$ and OI $(-25 \%)$, being an expected behaviour due to the nature of 


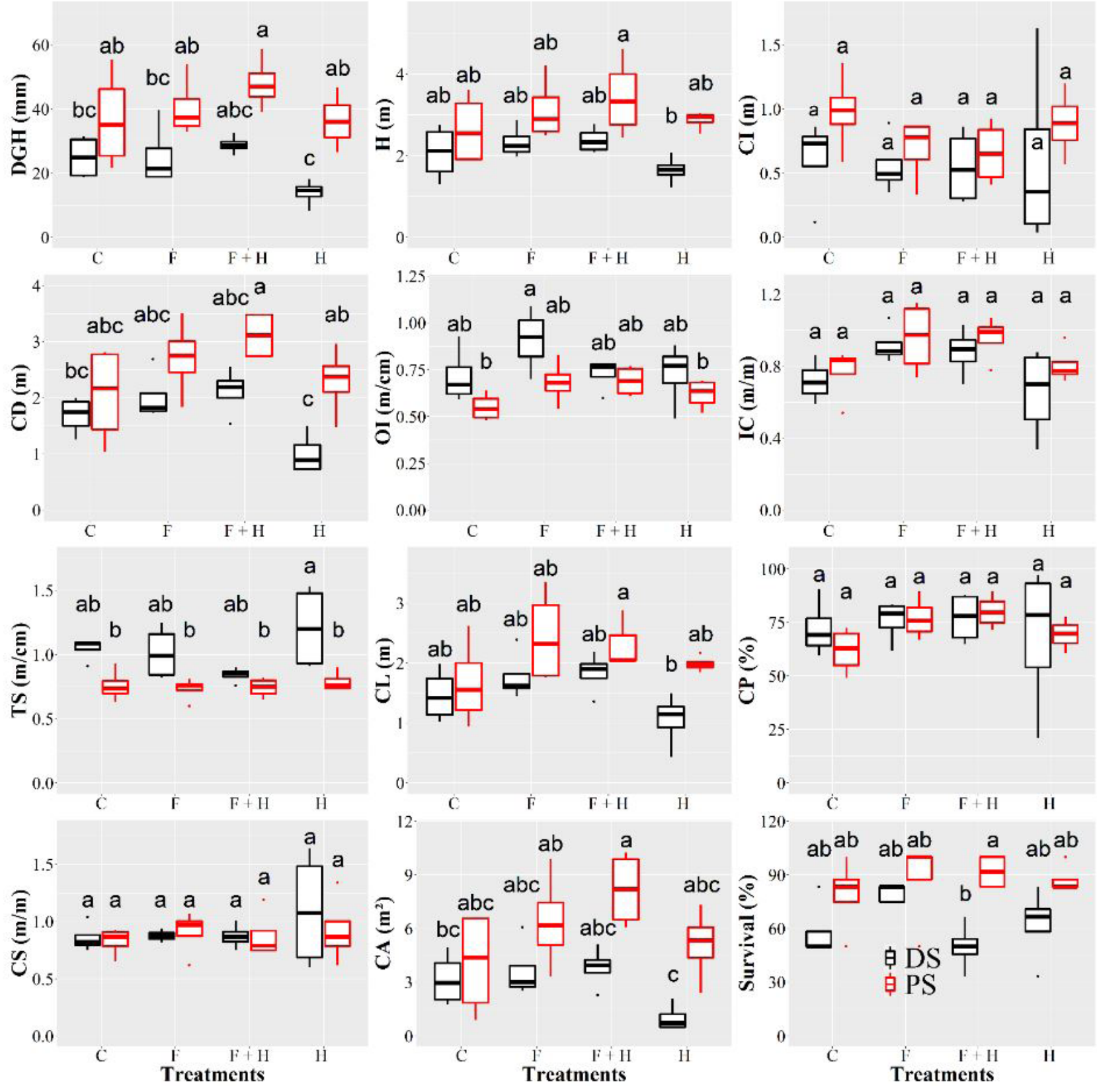

Figure 4. Tukey test result of the morphometric variables for Senegalia. DS: direct seeding; PS: planting seedlings; DGH: diameter at ground height; $\mathrm{H}$ : total height; $\mathrm{CI}$ : canopy insertion; CD: canopy diameter; OI: overhang index; IC: index comprehensive; TS: trunk slenderness; CL: canopy length; CP: canopy proportion; CS: canopy slenderness; CA: canopy area. C: control; F: fertilizer; F+H: fertilizer + hydrogel; H: hydrogel.

these variables. For the Schizolobium, there was not a marked differentiation between the two methods statistically, although direct seeding promoted the highest averages for DGB (11\%), H (5\%), CD (5\%), CI (16\%), CA (12\%), (Figure 5), with exceptions for CL $(-11 \%)$, CP (-16\%), TS (-6\%), CS (-29\%), OI $(-8 \%)$ and IC $(-4 \%)$. The combination of hydrogel and fertilizer $(\mathrm{F}+\mathrm{H})$ provided the highest results for almost all growth variables in both species and that there were no statistical differences between $\mathrm{F}+\mathrm{H}$ and fertilizer alone (A) in almost all morphometric descriptors. The exception could be detected for survival in Senegalia, where $\mathrm{F}+\mathrm{H}$ treatment at DS was significantly lower than in S.

\section{Discussion}

Regarding PCA and the positioning of the variables (H, DGH, CD, CL and CI) in the first axis (all positive), all variables grow synergistically, that is, as one variable increases, 


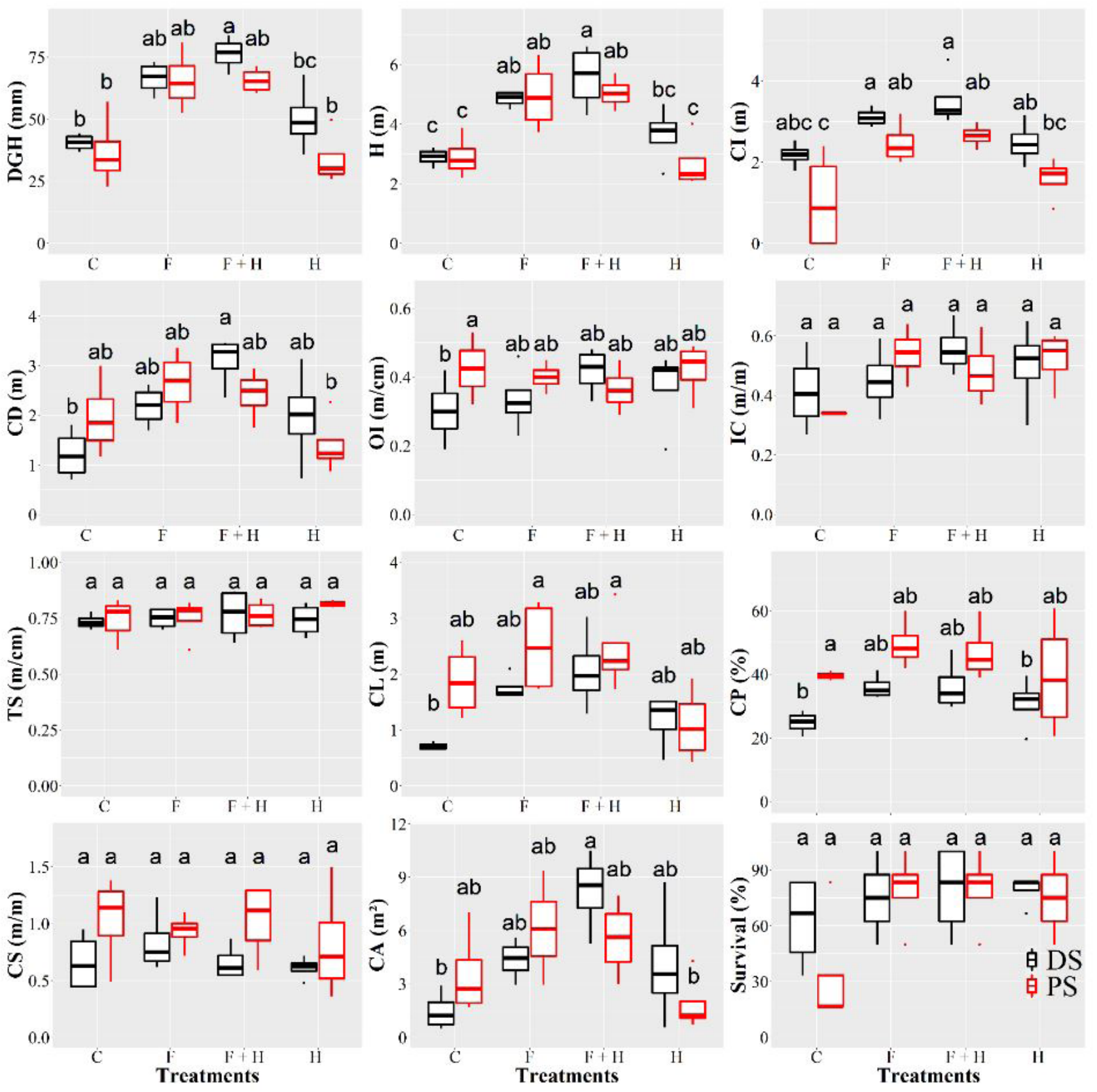

Figure 5. Tukey test result of the morphometric variables for Schizolobium. DS: direct seeding; PS: planting seedlings; DGH: diameter at ground height; $\mathrm{H}$ : total height; $\mathrm{CI}$ : canopy insertion; CD: canopy diameter; OI: overhang index; IC: index comprehensive; TS: trunk slenderness; CL: canopy length; CP: canopy proportion; CS: canopy slenderness; CA: canopy area. C: control; F: fertilizer; F+H: fertilizer + hydrogel; H: hydrogel.

the others also grow, as can be seen in Table 2. In other words, and according to well-known studies in the literature, there was a positive relationship between primary (height) and secondary (increase in stem and branch diameter) aspects of the plant. After 30 months of the implantation of forest, the species Senegalia showed a more significant difference between direct seeding and planting of seedlings, when represented in an order when compared to Schizolobium, and this may be related to relevant differences in some of the characteristics promoted by the two methods (p. ex. DGH, H, CL). The height and diameter of the trunk are important variables in forest research, where their relation $(\mathrm{DH})$ is the most commonly used measure to describe tree size or settlement (Mugasha et al., 2013; Sumida et al., 2013). The canopy seems to follow a similar pattern of growth, if there is no physiological or biomechanical restriction, as mentioned by Spatz \& Bruechert (2000), where tree growth is determined largely by physiological constraints. However, if these physiological contents are optimal, limitations in size 
Table 2. Spearman correlation of morphometric variables for Schizolobium and Senegalia.

\begin{tabular}{|c|c|c|c|c|c|c|c|c|c|c|}
\hline \multicolumn{11}{|c|}{ Schizolobium } \\
\hline & DGH & CI & $\mathbf{H}$ & CL & OI & IC & CP & CS & TS & CD \\
\hline \multicolumn{11}{|l|}{ DGH } \\
\hline $\mathrm{CI}$ & 0.75 & & & & & & & & & \\
\hline $\mathrm{H}$ & 0.92 & 0.77 & & & & & & & & \\
\hline $\mathrm{CL}$ & 0.75 & 0.36 & 0.82 & & & & & & & \\
\hline OI & -0.01 & 0.02 & 0.07 & 0.09 & & & & & & \\
\hline IC & 0.19 & 0.06 & 0.07 & 0.08 & 0.80 & & & & & \\
\hline $\mathrm{CP}$ & 0.33 & -0.17 & 0.39 & 0.83 & 0.09 & 0.05 & & & & \\
\hline CS & 0.16 & -0.17 & 0.27 & 0.60 & -0.42 & -0.57 & 0.75 & & & \\
\hline TS & -0.28 & -0.06 & 0.05 & 0.08 & 0.26 & -0.29 & 0.14 & 0.27 & & \\
\hline $\mathrm{CD}$ & 0.82 & 0.63 & 0.80 & 0.67 & 0.51 & 0.61 & 0.32 & -0.11 & -0.13 & \\
\hline \multicolumn{11}{|c|}{ Senegalia } \\
\hline & DGH & CI & $\mathbf{H}$ & CL & OI & IC & CP & CS & TS & CD \\
\hline \multicolumn{11}{|l|}{ DGH } \\
\hline $\mathrm{CI}$ & 0.33 & & & & & & & & & \\
\hline $\mathrm{H}$ & 0.89 & 0.37 & & & & & & & & \\
\hline $\mathrm{CL}$ & 0.73 & -0.18 & 0.80 & & & & & & & \\
\hline OI & -0.19 & -0.17 & -0.01 & 0.06 & & & & & & \\
\hline IC & 0.35 & -0.06 & 0.18 & 0.21 & 0.57 & & & & & \\
\hline $\mathrm{CP}$ & 0.05 & -0.89 & 0.06 & 0.57 & 0.17 & 0.14 & & & & \\
\hline CS & -0.17 & -0.63 & -0.06 & 0.34 & -0.25 & -0.54 & 0.66 & & & \\
\hline TS & -0.66 & -0.13 & -0.28 & -0.23 & 0.31 & -0.53 & 0.01 & 0.34 & & \\
\hline $\mathrm{CD}$ & 0.89 & 0.25 & 0.88 & 0.76 & 0.21 & 0.56 & 0.14 & -0.26 & -0.47 & \\
\hline
\end{tabular}

In bold significant correlation at 5\% probability. DGH: diameter at ground height; CI: canopy insertion; H: total height; CL: canopy length; OI: overhang index; IC: index comprehensive; CP: canopy proportion; CS: canopy slenderness; TS: trunk slenderness; CD: canopy diameter.

and shape are still imposed by biomechanical constraints, such as wind, which can affect plants with high values of trunk and canopy slenderness due to trunk and crown instability (Resende \& Resende, 2011; Moore \& Maguire, 2005; Tomczak et al., 2015). In this perspective, more unstable trunks were more displayed in Senegalia, with the DS method (Figure 4), in other words, the same method that presented the lowest total heights and trunk diameter for the species. Although taller plants are more susceptible to wind, the three-dimensional structure of the plant should be considered to understand the height limitation in relation to the effects of wind (Malhi et al., 2018).

The vertical growth in the initial phase, which is expected, can be seen in the positive correlations between SI and SC, or between SC and PC and, consequently, negative with OI and CI. Note, however, that SI correlated positively with OI and negatively with CI, which generally suggests that plants invest in canopy growth as a measure of stabilization, both in diameter and canopy length. The $\mathrm{CP}$ is the relation between canopy length and total plant height where the photosynthetic area of the plant is addressed, which in other words, means that higher percentage of the canopy, more productive is the plant (Durlo \& Denardi, 1998; Dubravac et al., 2009). However, the crown area is the result of genetic interactions and external biotic and abiotic factors that affect the plant (Adeyemi \& Adesoye,
2016) and hinder individual morphometric analyses. Based on this information, we propose the use of a combination of SI, SC and PC variables, with the OI and CI indexes, as well as the main measurable descriptors, such as DGH, H, CI and CL.

In the field implementation for Schizolobium, both methods were similar, while for Senegalia, the planting of seedlings showed better performance (Figure 5: DGH, H, CI, CD and CL). The great advantage of planting seedlings seems to be the guarantee of the essential conditions for implementation and survival in the field with the 'rustification', as highlighted by Caron et al. (2010) and Martins et al. (2012). However, it would be interesting to evaluate with a larger time scale to understand the growth of the plants via DS, since our research was performed at 30 months. Although the hydrogel combined with the SRF provided the best field performances, it did not achieve this characteristic alone (Figures 4 and 5). It is worth to mention that water-repellents are polymers that have a significant capacity for water absorption processes, that being combined with soils of coarse textures avoids the occurrence of water deficit, which is fundamental in field development (Oviedo et al., 2008), thus providing high survival rates (Figures 4 and 5). In addition, under non-limiting water conditions, hydrogels serve to enhance nutrient uptake for plant growth (Huttermann et al., 2009). While Osmocote ${ }^{\circledR}$ provides 
uninterrupted nutrients to plants over a considerable period of time, there is little possibility of nutrient deficiency occurring during the initial development of the plant. However, it should be noted that the pattern found here for hydrogel performance may not be found for other species in other locations where their maximum response may vary according to several factors, such as soil grading, soil water balance etc. In addition to the negative factors (Prevedello \& Loyola, 2007), and not counting the economic factor (Hafle et al., 2008), the researcher must always focus on the best strategy.

Based on the analyses carried out, we recommend the indices of protrusion, canopy ratio, canopy slenderness and trunk slenderness, as well as the main ones (trunk, height and canopy) in forest implantation. This action will improve our understanding of the vegetation structure, as well as to obtain these relationships within a temporal scale, since the associations are not static throughout the growth of the plants. Likewise, we recommend the application of the SRF as a complementary input in relation to the recovery objective of riparian areas.

\section{Conclusion}

The silvicultural indexes, according to the main variables of the plant, provide ancillary information for understanding the morphological growth pattern, and it should be essential to use these in the study of forests. The relevant differentiation in the attributes of Senegalia in relation to Schizolobium, evidenced in the PCA, reinforces the use of PCA as an auxiliary method in the scope of exploratory analysis. For Senegalia and Schizolobium, it could be noted that both direct seeding and planting seedlings provided satisfactory results, however, planting of seedlings resulted in best results for Senegalia, but with less statistical clarity for Schizolobium. Regarding the applications, we recommend the use of the SRF as complementary inputs in forest implantation.

\section{Submission status}

Received: 17 June, 2019

Accepted: 14 Apr., 2020

Associated Editor: Eduardo Vinicius da Silva.

\section{Correspondence to}

\section{Antônio Carlos Silveiro Silva}

Universidade do Estado de Mato Grosso (UNEMAT), Programa de Pós-graduação em Ecologia e Conservação, Rua Rio Branco, Canarana, CEP 78640-000, Nova Xavantina, MT, Brasil e-mail: acsilveiro@gmail.com; acsilveiro@gmail.com

\section{References}

Adeyemi AA, Adesoye PO. Tree slenderness coefficient and percent canopy cover in Oban Group Forest, Nigeria. Journal of Natural Sciences Research 2016; 6(4): 9-17.

Almeida DS. Modelos de recuperação ambiental. In: Almeida DS, editor. Recuperação ambiental da Mata Atlântica. 3rd ed. Ilhéus: Editus; 2016. http://dx.doi.org/10.7476/9788574554402.0009.
Alvares CA, Stape JL, Sentelhas PC, Gonçalves JLM, Sparovek G. Köppen's climate classification map for Brazil. Meteorologische Zeitschrift 2013; 22(6): 711-728. http://dx.doi.org/10.1127/09412948/2013/0507.

Bleich ME, Silva CJ. Caracterização dos fragmentos florestais amazônicos remanescentes na microbacia hidrográfica do rio Taxidermista I em Alta Floresta, MT. Biotemas 2013; 26(4): 45-51. http://dx.doi.org/10.5007/2175-7925.2013v26n4p45.

Brasil. Lei no 12.651, de 25 de maio de 2012. Dispõe sobre a proteção da vegetação nativa; altera as Leis $n^{\circ}$ s 6.938, de 31 de agosto de 1981, 9.393, de 19 de dezembro de 1996, e 11.428, de 22 de dezembro de 2006; revoga as Leis $n^{\circ}$ S 4.771, de 15 de setembro de 1965, e 7.754, de 14 de abril de 1989, e a Medida Provisória no 2.166-67, de 24 de agosto de 2001; e dá outras providências [online]. Diário Oficial da República Federativa do Brasil, Brasília, DF (2012 maio) [cited 2020 Jan 8]. Available from: http://www.planalto.gov.br/ccivil_03/_ato20112014/2012/lei/l12651.htm

Carnevali NHS, Santiago ET, Daloso DM, Carnevali TO, Oliveira MT. Sobrevivência e crescimento inicial de espécies arbóreas nativas implantadas em pastagem degradada. Floresta 2016; 46(2): 277-286. http://dx.doi.org/10.5380/rf.v46i2.42881.

Caron OB, Souza QV, Cantarelli BE, Manfron PA, Behling A, Eloy E. Crescimento em viveiro de mudas de Schizolobium parahyba (Vell.) SF Blake. submetidas a níveis de sombreamento. Ciência Florestal 2010; 20(4): 683-689. http://dx.doi.org/10.5902/198050982427.

Carvalho AO, Bergamin AC, Evaristo AP, Neves AHB, Carmo CCA, Guimarães JNS Jr. Initial growth of 'paricá' (Schizolobium amazonicum) seedlings under different nitrogen doses. Nativa 2016; 4(2): 112-115. http://dx.doi.org/10.14583/2318-7670.v04n02a11.

Ceccon E, González EJ, Martorell C. Is direct seeding a biologically viable strategy for restoring forest ecosystems? Evidences from a meta-analysis. Land Degradation \& Development 2016; 27(3): 511520. http://dx.doi.org/10.1002/ldr.2421.

Cordeiro IMCC, Barros PLC, Lameira OA, Gazel AB Fo. Avaliação de plantios de Paricá (Schizolobum parahyba var. amazonicum (Huber ex Ducke) Barneby de diferentes idades e sistemas de cultivo no município de Aurora do Pará-PA (Brasil). Ciência Florestal 2015; 25(3): 679-687. http://dx.doi.org/10.5902/1980509819618.

Dassot M, Constant T, Fournier M. The use of terrestrial LiDAR technology in forest science: application fields, benefits and challenges. Annals of Forest Science 2011; 68(1): 959-974. http:// dx.doi.org/10.1007/s13595-011-0102-2.

Dubravac T, Dekanic S, Vrbek B, Matosevic D, Roth V, Jakovljevic $\mathrm{T}$ et al. Crown volume in forest stands of pedunculate oak and common hornbeam. Periodicum Biologorum 2009; 111(4): 479-485.

Durlo MA, Denardi L. Morphometry for Cabralea canjerana in native secondary forest in Rio Grande do Sul. Ciência Florestal 1998; 8(1): 55-66. http://dx.doi.org/10.5902/19805098351.

Elbarbary AM, Ghobashy MM. Controlled release fertilizers using superabsorbent hydrogel prepared by gamma radiation. Radiochimica Acta 2017; 105(10): 865-876. http://dx.doi.org/10.1515/ract-2016-2679.

Florentine SK, Graz FP, Ambrose G, O'Brien L. The current status of different age, direct-seeded revegetation sites in agricultural landscape in the Burrumbeet Region, Victoria, Australia. Land 
Degradation \& Development 2013; 24(1): 81-89. http://dx.doi. org/10.1002/ldr.1110.

Grossnickle SC, Ivetić V. Direct seeding in performance review: a reforestation field. Reforesta 2017; 4: 94-142. http://dx.doi. org/10.21750/REFOR.4.07.46.

Hafle OM, Cruz MCM, Ramos JD, Ramos PS, Santos VA. Production of seedlings of sweet passion fruit by vegetative propagation using hydrophilic polymer. Agrária 2008; 3(3): 232-236. http://dx.doi. org/10.5039/agraria.v3i3a292.

Helfenstein J, Kienast F. Ecosystem service state and trends at the regional to national level: a rapid assessment. Ecological Indicators 2014; 36(1): 11-18. http://dx.doi.org/10.1016/j.ecolind.2013.06.031.

Holl KD, Zahawi RA, Cole RJ, Ostertag R, Cordell S. Planting seedlings in tree islands versus plantations as a large-scale tropical forest restoration strategy. Restoration Ecology 2011; 19(4): 470-479. http://dx.doi.org/10.1111/j.1526-100X.2010.00674.x.

Huller A, Coelho GC, Meneghello GE, Peske ST. Evaluation of direct seeding and seedling planting of two neotropical tree species with the use of natural inputs. Revista Árvore 2017; 41(4): 1-8. http:// dx.doi.org/10.1590/1806-90882017000400005.

Huttermann A, Orikiriza LJB, Agaba H. Application of superabsorbent polymers for improving the ecological chemistry of degraded or polluted lands. Clean: Soil, Air, Water 2009; 37(7): 517-526.

Kassambara A, Mundt F. factoextra: extract and visualize the results of multivariate data analyses. $R$ package version 1.0.3. Vienna: $R$ Foundation for Statistical Computing; 2016.

Le S, Josse J, Husson F. FactoMineR: an R package for multivariate analysis. Journal of Statistical Software 2008; 25(1): 1-18. http:// dx.doi.org/10.18637/jss.v025.i01. PMid:19777145.

Leitão FHM, Marques MC, Ceccon E. Young restored forests increase seedling recruitment in abandoned pastures in the Southern Atlantic rainforest. Revista de Biología Tropical 2010; 58(4): 12711282. PMid:21246991.

Lowman MD, Schowalter TD. Plant science in forest canopies: the first 30 years of advances and challenges (1980-2010). The New Phytologist 2012; 194(1): 12-27. http://dx.doi.org/10.1111/j.14698137.2012.04076.x. PMid:22348430.

Machado DLM, Lucena CC, Santos D, Siqueira DL, Matarazzo PHM, Struiving TB. Slow-release and organic fertilizers on early growth of Rangpur lime. Revista Ceres 2011; 58(3): 359-365. http:// dx.doi.org/10.1590/S0034-737X2011000300017.

Maia-Silva C, Silva CI, Hrncir M, Queiroz RT, Imperatriz-Fonseca VL. Guia de plantas visitadas por abelhas na caatinga. 1. ed. Fortaleza: Fundação Brasil Cidadão; 2012.

Malhi Y, Tobias J, Lisa PB, Alvaro L, Alexander S, Martin H et al. New perspectives on the ecology of tree structure and tree communities through terrestrial laser scanning. Interface Focus 2018; 8(2): 20170052. http://dx.doi.org/10.1098/rsfs.2017.0052. PMid:29503728.

Martins CC, Borges ADS, Pereira MRR, Lopes MTG. Posição da semente na semeadura e tipo de substrato sobre a emergência e crescimento de plântulas de Schizolobium parahyba (Vell.) SF Blake. Ciência Florestal 2012; 22(4): 845-852. http://dx.doi. org/10.5902/198050987565.
Mendiburu F. agricolae: Statistical Procedures for Agricultural Research. $R$ package version 1.2-8 [online]. Vienna: R Foundation for Statistical Computing; 2017 [cited 2020 Jan ]. Available from: https://CRAN.R-project.org/package=agricolae

Moore JR, Maguire DA. Natural sway frequencies and damping ratios of trees: influence of crown structure. Trees 2005; 19(4): 363373. http://dx.doi.org/10.1007/s00468-004-0387-y.

Morim MP, Barros MJF. Senegalia. In: Jardim Botânico do Rio de Janeiro - JBRJ. Lista de espécies da Flora do Brasil [online]. Rio de Janeiro: JBRJ; 2015 [cited 2020 Jan ]. Available from: http:// floradobrasil.jbrj.gov.br/jabot/floradobrasil/FB100997

Mugasha WA, Bollandsås OM, Eid T. Relationships between diameter and height of trees in natural tropical forest in Tanzania. Southern Forests 2013; 75(4): 221-237. http://dx.doi.org/10.2989/ 20702620.2013.824672.

Nakamura A, Kitching RL, Cao M, Creedy TJ, Fayle TM, Freiberg $\mathrm{M}$ et al. Forests and their canopies: achievements and horizons in canopy science. Trends in Ecology \& Evolution 2017; 32(6): 438451. http://dx.doi.org/10.1016/j.tree.2017.02.020. PMid:28359572.

Nunes YRF, Fagundes NCA, Veloso MDM, Gonzaga APD, Domingues EBS, Almeida HS et al. Sobrevivência e crescimento de sete espécies arbóreas nativas em uma área degradada de floresta estacional decidual, norte de Minas Gerais. Revista Árvore 2015; 39(5): 801-810. http://dx.doi.org/10.1590/0100-67622015000500003.

Oviedo IR, Mendez NAN, Gomez MPG, Rodriguez HC, Martinez AR. Design of a physical and nontoxic crosslinked poly (Vinyl Alcohol) hydrogel. International Journal of Polymeric Materials and Polymeric Biomaterials 2008; 57(12): 1095-1103. http://dx.doi. org/10.1080/00914030802341661.

Prevedello CL, Loyola JMT. Effect of water-retaining polymers on infiltration of water into soil. Scientia Agraria 2007; 8(3): 313-317. http://dx.doi.org/10.5380/rsa.v8i3.8592.

R Core Team. (2017). R: a language and environment for statistical computing. Vienna: R Foundation for Statistical Computing.

Reis CAF, Paludzyszyn E Fo. Estado da arte de plantios com espécies florestais de interesse para o Mato Grosso. Colombo: Embrapa Florestas; 2011.

Resende SAA, Resende JC Jr. Interferência dos ventos no cultivo de plantas: efeitos prejudiciais e práticas preventivas. Enciclopédia Biosfera 2011; 7(12): 1-6.

Rust S. Analysis of regional variation of height growth and slenderness in populations of six urban tree species using a quantile regression approach. Urban Forestry \& Urban Greening 2014; 13(2): 336-343. http://dx.doi.org/10.1016/j.ufug.2013.12.003.

Santos MRA, Marques O, Rocha JF, Vieira A. Early development of Schizolobium amazonicum seedlings under different cultivation conditions. Australian Journal of Basic and Applied Sciences 2016; 10(18): 60-65.

Souza ALT, Fonseca DG, Libório RA, Tanaka MO. Influence of riparian vegetation and forest structure on the water quality of rural loworder streams in SE Brazil. Forest Ecology and Management 2013;298(1): 12-18. http://dx.doi.org/10.1016/j.foreco.2013.02.022.

Spatz HC, Bruechert F. Basic biomechanics of self-supporting plants: wind loads and gravitational loads on a Norway spruce tree. Forest 
Ecology and Management 2000; 135(1-3): 33-44. http://dx.doi. org/10.1016/S0378-1127(00)00296-6.

Sumida A, Miyaura T, Torii H. Relationships of tree height and diameter at breast height revisited: analyses of stem growth using 20-year data of an even-aged Chamaecyparis obtusa stand. Tree Physiology 2013; 33(1): 106-118. http://dx.doi.org/10.1093/treephys/ tps127. PMid:23303367.

Tomczak A, Redzimska M, Jelonek T, Bułaj B. Allometric relationships between trunk slenderness and crown dimensions in Scots pine. Prace Komisji Nauk Rolniczych i Komisji Nauk Lesnych 2015; 108(108): 20-26.
Wickham H. ggplot2: elegant graphics for data analysis. 1st ed. New York: Springer-Verlag; 2009.

Yamamoto CF, Pereira EI, Mattoso LHC, Matsunaka T, Ribeiro C. Slow release fertilizers based on urea/urea-Formaldehyde polymer nanocomposites. Chemical Engineering Journal 2016; 287(1): 390397. http://dx.doi.org/10.1016/j.cej.2015.11.023.

Zimbres B, Machado RB, Peres CA. Anthropogenic drivers of headwater and riparian forest loss and degradation in a highly fragmented southern Amazonian landscape. Land Use Policy 2018; 72(1): 354-363. http://dx.doi.org/10.1016/j. landusepol.2017.12.062. 